\title{
Introduction \\ Severe community acquired pneumonia update: mortality, mechanisms and medical intervention
}

\author{
Pierre-Francois Laterre
}

St Luc University Hospital, Université Catholique de Louvain, Brussels B-1200, Belgium

Corresponding author: Pierre-Francois Laterre, laterre@rean.ucl.ac.be

Published: 26 November 2008

This article is online at http://ccforum.com/content/12/S6/S1

(c) 2008 BioMed Central Ltd
Critical Care 2008, 12(Suppl 6):S1 (doi:10.1186/cc7024)

Professor Rello has been actively involved in clinical research for the past 20 years, focusing on the prevention and control of hospital-acquired infections, severe CAP and treatment of infections in critically ill patients. His presentation focused on the epidemiology, diagnosis and severity scoring of severe $\mathrm{CAP}$, and the impact that treatment guidelines have had [5].

Tom van der Poll MD, PhD is Head of the Centre for Experimental and Molecular Medicine in the Academic Medical Centre in Amsterdam. His research is based in the Centre for Infection and Immunity Amsterdam (CINIMA) and focuses on innate immune responses to bacterial and mycobacterial infection. He also serves on the Steering Committee of the International Sepsis Forum. His presentation focused on the pathogenesis of severe CAP, in particular covering the roles played by TF as a critical component of the infectious, inflammatory and coagulation pathways [6].

Pierre-François Laterre MD is Head of the Intensive Care Unit at St. Luc University Hospital, Université Catholique de Louvain in Brussels, Belgium. Professor Laterre's professional and scientific activities have focused on the diagnosis, investigation and treatment of sepsis, particularly its interaction with the coagulation cascade. As Co-Chair for the symposium, his presentation focused on the rationale for TF as a therapeutic target in severe CAP and reviewed the design of the ongoing phase III CAPTIVATE study of tifacogin [7].

Jean-Paul Mira MD is Professor of Critical Care Medicine and Chair of the Medical Intensive Care Unit at the Cochin University Hospital; he is also Head of the Variability of Innate Immunity Research Laboratory at the Cochin Institute, both in Paris, France. His research interests are cellular responses to micro-organisms, Toll-like receptor signalling, functional genomics, genetic predisposition to sepsis and sepsisinduced immunosuppression. His presentation focused on the potential for biomarkers to assist physicians in the diagnosis of severe CAP and their possible future role in directing appropriate treatment [8].

Jordi Rello MD, PhD is Chief of the Critical Care Department at the Joan XXIII University Hospital in Tarragona, Spain. 
The second Co-Chair, Steve Opal MD, who is Professor of Medicine from the Brown Medical School, Pawtucket, Rhode Island, USA, hosted the questions from the audience and directed responses from faculty.

\section{Competing interests}

PFL was engaged in the conduct of the CAPTIVATE study, is a member of the clinical evaluation committee of the CAPTIVATE study, and served as a consultant for Novartis and received speaker fees.

\section{Acknowledgement}

This article is based on a presentation made at a satellite symposium, 'Severe community-acquired pneumonia update: mortality, mechanisms and medical intervention', held on 21 April 2008 in Barcelona, Spain as part of the 18th European Congress of Clinical Microbiology and Infectious Diseases (ECCMID). It is published as part of Critical Care Volume 12 Supplement 6,2008 . The full contents of the supplement are available online at http://ccforum.com/supplements/12/S6

Publication of the supplement has been sponsored by Novartis.

\section{References}

1. Restrepo MI, Mortensen EM, Velez JA, Frei C, Anzueto A: A comparative study of community-acquired pneumonia patients admitted to the ward and the ICU. Chest 2008, 133:610-617.

2. Feikin DR, Schuchat $A$, Kolczak M, Barrett NL, Harrison LH, Lefkowitz L, McGeer A, Farley MM, Vugia DJ, Lexau C, Stefonek $\mathrm{KR}$, Patterson JE, Jorgensen JH: Mortality from invasive pneumococcal pneumonia in the era of antibiotic resistance, 19951997. Am J Public Health 2000, 90:223-229.

3. Gando S, Kameue T, Morimoto Y, Matsuda N, Hayakawa M, Kemmotsu O: Tissue factor production not balanced by tissue factor pathway inhibitor in sepsis promotes poor prognosis. Crit Care Med 2002, 30:1729-1734.

4. Niessen F, Schaffner F, Furlan-Freguia C, Pawlinski R, Bhattacharjee G, Chun J, Derian CK, Andrade-Gordon P, Rosen H, Ruf W: Dendritic cell PAR1-S1P3 signalling couples coagulation and inflammation. Nature 2008, 452:654-658.

5. Rello J: Demographics, guidelines, and clinical experience in severe community-acquired pneumonia. Crit Care 2008, 12 (Suppl 6):S2.

6. van der Poll T: Tissue factor as an initiator of coagulation and inflammation in the lung. Crit Care 2008, 12(Suppl 6):S3.

7. Laterre PF: Beyond antibiotics in severe community-acquired pneumonia: the role and rationale for tissue factor pathway inhibition. Crit Care 2008, 12(Suppl 6):S4.

8. Mira JP, Max A, Burgel PR: The role of biomarkers in community-acquired pneumonia: predicting mortality and response to adjunctive therapy. Crit Care 2008, 12(Suppl 6):S5. 